\title{
TEACHING ONLINE IN PANDEMIC TIME: THE EXPERIENCE OF INDONESIAN EFL TEACHERS
}

\author{
Aji Budi Rinekso, \\ Universitas Pendidikan Indonesia \\ ajibudirinekso@upi.edu \\ Akhmad Bukhori Muslim², \\ Universitas Pendidikan Indonesia \\ abukhmuslim@upi.edu \\ Okta Lesagia ${ }^{3}$ \\ Universitas Negeri Yogyakarta \\ oktalesagia.2019@student.uny.ac.id
}

\begin{abstract}
Myriad studies reported abrupt transition of face-to-face classrooms to online learning due to pandemic and the results were various, contextually-bounded from country to another. Yet, studies exploring the aforementioned issue in Indonesian EFL context are still scarce. This study explores issues and challenges experienced by Indonesian EFL teachers in conducting English online learning during the pandemic within qualitative approach. Twentyfive secondary English teachers from urban, suburban, rural and remote area participated in this study. Subsequently, online questionnaire and semi-structured virtual interviews were employed to collect data. Then, the data were analyzed descriptively and thematically. The results showed that the participants had positive responses to online learning to maintain learning processes in pandemic time. In terms of teaching language skills, the participants argued that speaking is the most challenging to teach online. Moreover, the study identified three types of online learning challenges related to technical aspects, teachers and students. Pedagogically, this study implied that pandemic time has given teachers disguised blessings as they had an opportunity to upgrade their information technology skills and literacies.
\end{abstract}

Keywords: Indonesian EFL teachers, issues and challenges, online learning, teaching in pandemic time

\section{A. INTRODUCTION}

he global pandemic has impacted various landscapes of our lives including education. Since Covid-19 is highly contagious, social distancing as well as physical L distancing were imposed to reduce the spread of the virus. Correspondingly, all activities including the teaching and learning process should be done from home. Then, it was suggested for school administrators and teachers to limit even avoid meeting in classrooms and any other locations taking place in schools (World Health Organization, 2020). As a result, school closures become the wisest policy imposed by the Indonesian Ministry of Education and Culture to prevent the spread of the virus.

During school closures, teachers and students have to conduct teaching and learning process virtually. In this case, Indonesian Ministry of Education and Culture developed an online learning platform, namely "portal rumah belajar" which serves online class and learning materials. Besides, the ministry invites some startup companies to contribute to this situation 
by serving qualified online learning platforms. They are Google Indonesia, Kelas Pintar, Microsoft, Quipper, Ruangguru, Sekolahmu and Zenius. Those platforms are available to be used by teachers and students to conduct the teaching and learning process in the pandemic time (Kemdikbud, 2020). Those online learning platforms are Android-based applications and can be easily accessed by students and teachers freely with their own smartphones. However, teachers can utilize other platforms such as Google Classroom, Zoom, Google Meet, Edmodo and WhatsApp as long as the applications support the learning process.

Issues and challenges of teaching English mediated by online learning during pandemic time were various and very contextual in every country. Yet, studies exploring English online teaching in pandemic time within Indonesian EFL context are still scarce. Therefore, this study specifically aims at investigating issues and challenges experienced by Indonesian EFL teachers when conducting English online learning within the pandemic time. Thus, this study tries to answer the following research questions.

1. What are the EFL teachers' responses towards online learning during the pandemic?

2. What are the challenges faced and strategies done by the EFL teachers in conducting online learning during the pandemic?

\section{B. REVIEW OF LITERATURE}

\section{Online Learning during Pandemic}

The use of online learning increases significantly due to the pandemic time. Online learning refers to the integration of learning materials and other supportive resources with technological tools such as computer and internet (Carliner, 2004). Now, many studies are discussing designs and strategies of online instruction within this pandemic (Code et al., 2020; Dreamson, 2020; Mahmood, 2020; Zia, 2020). Essentially, the aim of online learning is omitting the border between students and teachers in terms of time and location. Through online learning, they can interact as well as do the teaching and learning process in a flexible time schedule without worrying about their distance. Contextually, this relates to this pandemic time where teachers and students have distance due to the prohibition of close range physical interactions. Besides, online learning allows students to interact directly with learning materials in form of various multiple formats such as video, audio and document (Huang et al., 2020). The students can easily download the learning materials given/recommended by their teachers and later on they can study the materials. This is supposed to be quite effective since today's students are commonly digital native. 
Moreover, online learning offers two types of learning environments: synchronous environment and asynchronous environment (Singh \& Thurman, 2019). Synchronous learning refers to the more structured learning in which the course is scheduled and delivered in live virtual classrooms and students will get real time interaction as well as feedback or instant messages from teachers. Meanwhile, in asynchronous learning students do not get real time or instant feedback from the teachers and the learning materials are not provided in live class but rather on different learning management systems (Huang et al., 2020). Correspondingly, online learning platforms provided by the Indonesian Ministry of Education and Culture can be used both for synchronous and asynchronous learning. Thus, teachers just decide what kind of learning activities that they want to conduct. If the teachers want to explain materials directly, they may conduct the synchronous learning. On the other hand, if the teachers just intend to give assignments or projects, then the learning environment will be categorized as asynchronous learning.

It is true that more research and teacher training administering the issue of offline to online learning transition under the event of health emergencies should be conducted soon (Moorhouse, 2020) as collaborative works among professional communities and practitioner leaders could bear valuable solutions (Knight, 2020). During this pandemic, the training can be held through video conferences, webinars and demo videos in order to maintain the physical distancing. The pandemic becomes tough test for countries around the world including Indonesia. From this hard situation, we ought to still think positively by believing that every hard situation always brings positive impact. The systems and skills gained from online learning format can be useful for teachers to conduct future teaching after the pandemic period such as in emergency situation or teaching students with special needs (Basilaia \& Kvavadze, 2020). Likewise, many online education researchers and practitioners may see the other side of this pandemic as a unique opportunity to support students, teachers and institutions for filling the gap of the current limitation of face-to-face instruction (Vlachopoulos, 2020). As a result, the innovation in the field of online learning can always be updated and upgraded.

\section{Previous Related Studies}

Some studies already discussed the issue of conducting online learning within pandemic time. The first is a case study talking about the six-step online teaching method based on protocol-guided learning during the pandemic in Changyuan City, Henan Province, China (Cai $\&$ Wang, 2020). The six steps include 1) teachers assign learning tasks, 2) students prepare and pre-study according to the protocol, complete homework and communicate within group, 3) 
Renekso, Muslim, Lesagia, Teaching Online in Pandemic...

parental supervision and teacher guidance, 4) the problem feedback, layer by layer, 5) teachers' online lecture guidance, problem correction and re-feedback, and 6) consolidation and promotion, summary and sublimation. The study revealed that doing the online learning by following those six steps improved students' autonomous learning ability.

The second study also confirmed that online learning during the pandemic time may lead to the improvement of students' autonomous learning since they learned independently from home with limited teachers' direct guidance (Xie \& Yang, 2020). However, the study found problems encountered the students in developing their autonomous learning. The problems were the different family conditions of students (led to the impossibility of all students to participate in the online learning) and lack of targeted autonomous learning materials. Thus, the study suggested solutions by strengthening the construction of online learning platforms to accommodate students' autonomous learning and prepare targeted learning materials to promotes students' autonomous learning.

The third study investigated the capacities of Georgia and its population to continue the education process at schools through online learning (Basilaia \& Kvavadze, 2020). The study identified the statistical usage of Google meet by 950 students in a private school within the first week of online education process. The results showed that quick transition from the traditional to the online education systems was already successful in Georgia. It implies that teachers, students and school administrators there already adapted to employ online learning in this pandemic time. Educational systems and skills contributed by the teachers, students and school administrators could be beneficial for post pandemic time. Likewise, lessons learned from the pandemic time could generate new policies, regulations, and solutions for future cases.

Different from those studies, the fourth study claimed that Ghanaian students were unable to study effectively from their houses through online learning systems during the pandemic time (Owusu-Fordjour et al., 2020). The study argued that in most countries, online learning was effective to be applied during the pandemic but it was ineffective to be applied in developing countries like Ghana. Many homes in Ghana did not provide adequate learning environment and it distracted the students' concentration to study. In addition, poor internet access and technological devices such as phones, computers and tablets also emerged as the problems. Consequently, the situations become challenges for Ghanaian and other developing countries' students. 


\section{RESEARCH METHOD}

\section{Research Design}

This study explored how Indonesian EFL teachers responded to the implementation of online learning during the outbreak of Covid-19 pandemic. An case study was selected to be the procedure for conducting this research as this research design seeks for uncovering context-bound social practices of a specific occasion and treats it as a single case (Creswell \& Poth, 2018; Yin, 2016). Correspondingly, this study puts a group of secondary EFL teachers handling teaching and learning process in pandemic time as a single case. The teachers' responses towards online learning policy, challenges of conducting online learning and how did the teachers deal with that were deeply explored in this study.

\section{Instruments}

The instruments of the study were online questionnaire and semi-structured interview. The instruments were constructed based on Anderson's Online Learning Model (Anderson, 2008) which represent the main actors of online learning: teachers, students and contents/materials. It assisted this study to explore online teaching-learning practices in a compact way. Additionally, the model was frequently referred by studies in the field of online education (Dabbagh \& Kitsantas, 2012; Lin, 2011; Selwyn, 2012; Stodel et al., 2006). Relied on this model, the present study tried to uncover issues and challenges found during the implementation of online learning in regards with the three domain actors from the views of the participants.

\section{Participants}

Twenty-five secondary English teachers voluntarily filled out the online questionnaire. Subsequently, nine of them were selected purposively to join the interview. The selection considers some aspects including school levels, years of teaching experiences, teachers' locations and willingness to join the interview. The process of collecting data was conducted virtually. Google Forms were used to design the online questionnaire while WhatsApp Voice Notes were used to record the participants' voices during the interview. The interview sections took around 30 minutes for each participant and were done during June-July 2020.

\section{Data analysis}

The questionnaire data were analyzed through descriptive statistics by calculating the frequency and the percentage of data distribution. The questionnaire used likert scale as follows: Strongly Agree/SA (value = 4), Agree/A (value = 3), Disagree/D (value = 2), and Strongly Disagree/SD (value =1). Then, the calculation is based on the following formula. 
Renekso, Muslim, Lesagia, Teaching Online in Pandemic...

$\frac{\text { total score per questionnaire item }}{100} \times 100 \%$

The maximum score per item is 100 as it is assumed that all respondents select SA (4 x 25 respondents). Thus, the calculation results are categorized as follows:

$\begin{array}{llll}\text { Strongly Disagree (SD) } & =1 \%-25 \% & \text { Agree (A) } & =51 \%-75 \% \\ \text { Disagree (D) } & =26 \%-50 \% & \text { Strongly Agree (SA) } & =76 \%-100 \%\end{array}$

Meanwhile, the interview data were analyzed thematically by following the three stages of qualitative data analysis suggested by Miles and Huberman (1994), Miles, Huberman and Saldana (2014) covering data condensation, data display and drawing/ verifying conclusions. Coding and memoing were done as well.

\section{FINDINGS AND DISCUSSION}

\section{Findings}

There were twenty-five respondents filling out the online questionnaire. The respondents of the questionnaire were various in terms of their school levels, years of teaching experiences, and teachers' locations. Table 1 shows the summary of respondents' profile.

Table 1. The demographic of questionnaire respondents

\begin{tabular}{lll}
\hline \multirow{2}{*}{ Category } & Sub-category & Total \\
\hline \multirow{2}{*}{ School levels } & Junior high school & $14(56 \%)$ \\
\cline { 2 - 3 } & Senior high school & $8(32 \%)$ \\
\cline { 2 - 3 } Yearational high school & $3(12 \%)$ \\
\hline \multirow{2}{*}{\begin{tabular}{l} 
Vexperience \\
\multirow{2}{*}{ Teachers' locations }
\end{tabular}} & Less than 5 years & $14(56 \%)$ \\
\cline { 2 - 3 } & 5-10 years & $5(20 \%)$ \\
\cline { 2 - 3 } & More than 10 years & $6(24 \%)$ \\
\cline { 2 - 3 } & Urban & $5(20 \%)$ \\
\cline { 2 - 3 } & Suburban & $5(20 \%)$ \\
\cline { 2 - 3 } & Rural & $14(56 \%)$ \\
\hline
\end{tabular}

Next, among the twenty-five respondents, the researchers selected nine of them to join the interview section. Again, the selection was done purposively considering some aspects including school levels, years of teaching experiences, and teachers' location. Also, their willingness to be interviewed was highly considered by the researchers to maintain participants' rights as well as research ethics.

The description of the interview participants is presented as follows. They were 5 junior high school teachers, 3 senior high school teachers and 1 vocational high school teacher. Meanwhile, in terms of teaching experiences, 6 teachers were junior teachers with less than 5 years of teaching experiences, 2 teachers were already teaching for 5-10 years and 1 senior 
teacher with more than 10 years of teaching experiences. In addition, they were coming from various locations, 2 teachers lived in urban areas, 2 teachers stayed in suburban areas, 4 teachers were in rural areas and 1 teacher taught in remote area. Then, for the educational background, all of them had obtained bachelor degree. Table 2 presents the profile of the interview participants.

Table 2. The demographic of interview participants

\begin{tabular}{lllll}
\hline No. & $\begin{array}{l}\text { Participants } \\
\text { (Pseudonyms) }\end{array}$ & School levels & $\begin{array}{l}\text { Years of } \\
\text { teaching } \\
\text { experiences }\end{array}$ & $\begin{array}{l}\text { Teachers' } \\
\text { Locations }\end{array}$ \\
\hline $\mathbf{1}$ & Mawar & SMK (Vocational high school) & $5-10$ & Suburban \\
\hline $\mathbf{2}$ & Indah & SMA (Senior high school) & $5-10$ & Rural \\
\hline $\mathbf{3}$ & Cici & SMA (Senior high school) & $>10$ & Rural \\
\hline $\mathbf{4}$ & Didi & SMP (Junior high school) & $<5$ & Remote \\
\hline $\mathbf{5}$ & Lilis & SMP (Junior high school) & $<5$ & Urban \\
\hline $\mathbf{6}$ & Budi & SMP (Junior high school) & $<5$ & Rural \\
\hline $\mathbf{7}$ & Devi & SMP (Junior high school) & $<5$ & Rural \\
\hline $\mathbf{8}$ & Bambang & SMP (Junior high school) & $<5$ & Urban \\
\hline $\mathbf{9}$ & Sri & SMA (Senior high school) & $<5$ & Suburban \\
\hline
\end{tabular}

With various backgrounds including school levels, years of teaching experiences and locations, this study expected to gain more representative voices of the Indonesian EFL teachers in handling online English teaching during the pandemic.

\section{Teachers' Responses to Online Learning during Pandemic}

Rich information related to the issues of conducting online learning during the pandemic time were successfully gathered by the researchers. In accordance with the research questions, the information was categorized into three issues namely teachers' responses, challenges and strategies. The former issue, teachers' responses, reflect on how the EFL teachers see the implementation of online learning during the pandemic time. Meanwhile, the latter issues, challenges and strategies present the problems that the teachers found in online learning and how they cope the problems. For the latter issues, they are discussed in the next section.

As shown in table 3, there were three questionnaire items proposed to know teachers' responses towards the implementation of online learning during the pandemic. Firstly, the majority of the teachers agree that online learning is quite effective for conducting the teaching and learning process during the pandemic. It is proved by the calculation result of the item which shows $81 \%$. Secondly, most of the teachers believed that online learning trained students to be more autonomous in finding materials through online resources. More than half of the total of respondents agree with that argument as the calculation result shows $77 \%$. Lastly, the teachers confirmed that online learning provides flexibility (flexible time and space) in the process of conducting teaching and learning process. The statement reaches 
Renekso, Muslim, Lesagia, Teaching Online in Pandemic...

$70 \%$, meaning that almost all of the respondents agree with that. In short, the teachers showed positive responses towards the implementation of online learning during the pandemic.

Table 3. Questionnaire results of the teachers' responses to online learning

\begin{tabular}{|ll}
\hline Questionnaire/statement items & Responses \\
\hline Online learning is effective for teaching in emergency situation (pandemic). & $81 \%$ \\
\hline Online learning supports learner autonomy in terms of accessing materials. & $77 \%$ \\
\hline Online learning offers flexible instructions. & $70 \%$ \\
\hline
\end{tabular}

Moreover, the interview data resulted on some themes (see table 4). The themes represent teachers' opinion about several aspects of implementing online learning during the pandemic including 1) the government policy for imposing online learning during the pandemic time, 2) experiences in managing online learning, 3) the most challenging skill to teach online, 4) access for online resources/materials, 5) the reliability of learning materials, 6) the needs for materials adaptations, and 7) the role of online learning. In general, their responses were relatively positive.

Table 4. Interview results of the teachers' responses to online learning

\begin{tabular}{lll}
\hline No. & Themes/aspects & Responses \\
\hline $\mathbf{1}$ & $\begin{array}{l}\text { Online learning for } \\
\text { pandemic time }\end{array}$ & $\begin{array}{l}\text { Online learning is the best solution for maintaining learning } \\
\text { process during the pandemic time. }\end{array}$ \\
\hline $\mathbf{2}$ & $\begin{array}{l}\text { Experiences in managing } \\
\text { online learning }\end{array}$ & $\begin{array}{l}\text { Some teachers already had experiences in managing online } \\
\text { learning such as sharing materials via WhatsApp, conducting } \\
\text { online writing class and operating Google Classrooms. }\end{array}$ \\
\hline $\mathbf{3}$ & $\begin{array}{l}\text { The most challenging } \\
\text { language skills to teach } \\
\text { online }\end{array}$ & $\begin{array}{l}\text { The most challenging language to teach online is speaking. It } \\
\text { happens because students were used to be passive in face-to- } \\
\text { face classrooms. They were shy and not confident to speak } \\
\text { up. Besides, it is difficult for teachers to assess online } \\
\text { speaking performances. }\end{array}$ \\
\hline $\mathbf{4}$ & $\begin{array}{l}\text { Access for online } \\
\text { resources/materials }\end{array}$ & $\begin{array}{l}\text { Most teachers have good access for online resources. } \\
\text { The reliability of learning } \\
\text { materials }\end{array}$ \\
\hline $\mathbf{5}$ & $\begin{array}{l}\text { The materials provided by online learning platforms such as } \\
\text { Portal Rumah Belajar, Ruangguru, Zenius, and Quipper are } \\
\text { reliable. }\end{array}$ \\
\hline $\mathbf{7}$ & $\begin{array}{l}\text { The role of online learning } \\
\text { Thes. The materials need some adaptations in order to adjust } \\
\text { with every contextual teaching situation. }\end{array}$ & $\begin{array}{l}\text { Online learning facilitates students and teacher to do the } \\
\text { transfer of knowledge in pandemic time. Besides, online } \\
\text { learning makes students more resilient and encourages } \\
\text { teachers to upgrade IT literacy/competencies. }\end{array}$ \\
\hline
\end{tabular}

Firstly, the researchers asked teachers about how they perceive the employment of online learning by the government to maintain the learning process during the pandemic times. As disasters or any difficult times would relatively continue to occur and technology always helped us to cope with that, all of the teachers agreed that online learning was the best 
solution for maintaining learning process during the pandemic time. They saw online learning as the best way for bridging them and their students to do the transfer of knowledge without involving close range physical interaction.

"For this kind of situation, I can say this is the most proper solution for the education during the pandemic"

(Bambang)

Some teachers informed that they had experiences in managing online learning such as sharing materials via WhatsApp, conducting online writing class and creating online class through Google classrooms. In addition, one teacher also had experiences in doing online assessment by using Google form and BeeSmart (application for conducting school examination). The experiences for managing online learning were obtained through selfinitiative as well as PPG (professional teacher training program). Hence, the teachers benefited from their experiences in terms of having better preparation for conducting online learning during the pandemic time.

"Sometimes I ask the students to submit the task via YouTube or Instagram. And when I did PPG programs, I also used Whats App to share in the materials to the students"

Talking about teaching language skills in online learning mode, the majority of the teachers stated that speaking became the most challenging skill to teach. Firstly, many students were not confident to speak up. They were shy of making mistakes. Not necessarily in online learning, even in face-to-face classrooms, many students were always passive. The psychological factors influencing students to be reticent to participate in face-to-face speaking practices are relatively the same as in online classes. Secondly, live oral communications and direct feedback could not be done since teachers had to use light and low data usage applications such as WhatsApp group or Google Classrooms. Actually, live video conference applications such as Zoom, WebEx and Google Meet might be used by the teachers to teach speaking. In fact, most of their students still had poor internet connections and limited internet quota. Meanwhile, reading and writing became less challenging to teach since it could be done easily via online learning mode. Students were used to do reading tasks and answer it in form of written texts. They just read the tasks, wrote the answers and sent back to their teachers via WhatsApp Group or Google Classrooms.

"...most of my students, they are shy and not confident in speaking in English. It even happened in normal classes"

(Mawar) 
Renekso, Muslim, Lesagia, Teaching Online in Pandemic...

"This happens because my students cannot interact and get feedback at the same time"

To get learning materials from online resources, all of the teachers stated that they did not have problems with that. They had wi-fi internet connections at their homes. With this facility, the could easily browse many kinds of learning materials needed for their teaching. Portal Rumah Belajar, busyteacher.org, en.islcollective.com, YouTube, academia.edu were the websites that the teachers accessed for gaining online learning materials.

"Yes, I do. Because I have good access of internet connection, I also have resources offline that I can use in online learning"

Moreover, the researchers also asked teachers' opinions about learning materials provided by some online learning platforms such Portal Rumah Belajar (launched by Indonesian Ministry of Education and Culture), Ruangguru, Zenius and Quipper. In general, the teachers believed that the materials provided by those online learning platforms were reliable. Even, some of them use the materials frequently. They thought that learning materials served by those online learning platforms were developed thoroughly with some revisions and evaluations. However, they argued that sometimes teachers had to do modification on the materials in order to adjust with their teaching context. For example, simplifying reading texts to be accustomed with students' level of vocabulary mastery and adding extra exercises which employ higher order thinking skills.

"Those platforms are reliable for the teachers. But again, teachers will always modify some irrelevant materials because not all students in Indonesia have the same comprehension towards several materials"

(Bambang)

"In my opinion, they are reliable, but not affordable for my students."

Lastly, teachers argued that online learning played an important role in bridging them with their students as well as learning materials. Through online learning, teachers could still be connected with their students although they did not meet directly. Also, online learning facilitated teachers lots of learning materials that could be easily accessed. Moreover, teachers also saw the policy of using online learning mode in pandemic times encouraged them to upgrade information technology (IT) skills and literacy as well as shaped their students to be more resilient because of facing challenges in online learning. 
'T think most teachers including me realize that we need to upgrade not only about our subject but also about technology like finding new ways our new platform to convey our materials in the most attractive way for students. And for students, I think online learning trains them to be a resilient student"

\section{The Challenges and Strategies for Conducting Online Learning}

This section specifically discusses the challenges and strategies done by the participants during the employment of online learning in pandemic time. Two questionnaire items proposed to confirm the challenges of conducting the online learning (see table 5). Both of the questionnaire items get more than $90 \%$, indicating that most of the participants agree with the two statements. They confirmed that technical problems and unconducive home situation significantly contributed to the obstacle of online instructions.

Table 5. Questionnaire results of the challenges in conducting the online learning

\begin{tabular}{ll}
\hline Questionnaire/statement items & Responses \\
\hline $\begin{array}{l}\text { Sometimes, technical problems such as poor internet connection, limited } \\
\text { computers/PC/Laptop/Smartphones, limited skills for managing online }\end{array}$ & \\
learning and expensive internet quota become the barriers for conducting the \\
online class.
\end{tabular}

In the same way, the interview data showed three themes of challenges for conducting online learning namely technical problems, teachers' problems and students' problems (see table 6). Basically, the interview data share similar results with the questionnaire data. Yet, they have more detailed information and this can strengthen the findings of this study.

Table 6. The summary of challenges and strategies done during online learning

\begin{tabular}{|c|c|c|}
\hline $\begin{array}{l}\text { Types of } \\
\text { challenges }\end{array}$ & Descriptions & Strategies \\
\hline $\begin{array}{l}\text { Technical } \\
\text { problems }\end{array}$ & $\begin{array}{l}\text { - Limited internet } \\
\text { quota/access. } \\
\text { - Unavailability of } \\
\text { smartphones or } \\
\text { computers. } \\
\text { - Unfamiliarity of } \\
\text { using online } \\
\text { learning platforms. }\end{array}$ & $\begin{array}{l}\text { - Allocating BOS (Bantuan Operasional Sekolah/ School } \\
\text { Operational Fund) to provide internet quota/access } \\
\text { for students. } \\
\text { - Do not burden students with too much or difficult } \\
\text { assignments requiring lots of internet data usage. } \\
\text { - Watch English learning programs at TVRI. } \\
\text { - Ask some students to help others who did not have } \\
\text { - Chartphones or computers. } \\
\text { Whatsing to the simpler learning platform such as }\end{array}$ \\
\hline $\begin{array}{l}\text { Teachers' } \\
\text { problems }\end{array}$ & $\begin{array}{l}\text { - Preparing online } \\
\text { materials. } \\
\text { - Preparing online } \\
\text { assessments. }\end{array}$ & $\begin{array}{l}\text { - Preparing online materials and assessments long days } \\
\text { before the schedule of teaching. } \\
\text { - Watching YouTube to improve knowledge about } \\
\text { online assessment. }\end{array}$ \\
\hline $\begin{array}{l}\text { Students' } \\
\text { problems }\end{array}$ & $\begin{array}{l}\text { - Unconducive } \\
\text { home situations. } \\
\text { - Helping parents. }\end{array}$ & - Giving extra time for finishing tasks. \\
\hline
\end{tabular}


Renekso, Muslim, Lesagia, Teaching Online in Pandemic...

Firstly, technical problems became the most common problems in the implementation of online learning. Generally, this happens because some schools in rural and remote areas did not have proper facilities. Based on the teachers' experiences, they were difficult to teach online when some of their students could not join online classes because of limited internet quota/access. Some students did not have Wi-Fi internet connection at homes. Even, they could not afford to buy internet quota. Later on, some teachers allocated BOS Bantuan Operasional Sekolah) or School Operational Fund for buying internet quota for their students while the other teachers gave simpler assignments requiring low internet data usage. Also, the teachers suggested to watch English learning programs at TVRI (Official television channel managed by Indonesian government). Next, it was also reported by the teachers that some students did not have smartphones or laptops for joining the online classes. To cope this problem, teachers asked some students to help their friends who did have smartphones/computers. With this strategy, teachers could still keep contact with all of their students. Moreover, unfamiliarity of using online learning platforms might be a problem. Sometimes, sending documents/files, creating tasks deadline, checking students' presence, submitting tasks and archiving students' work became the challenges for teachers and students in their online classes. Therefore, some teachers preferred to use simpler application such as WhatsApp. Besides, simpler application also required less internet data usage.

"During online learning, there were several obstacles since my school is in a remote area so the students are not ready with online learning. Some even have no gadget at all"

Secondly, teachers also found some difficulties when they were preparing online classes. The teachers needed extra efforts for preparing online learning materials and assessments. Sometimes, the teachers also did some modifications on learning materials obtained from online resources. Meanwhile, in terms of preparing online assessments, the teachers had to consider the high possibility of cheating or plagiarizing. Consequently, the teachers had to modify their assessments to be more student-to-student interactions such as pair works and group projects. Open book exams were also suitable to be done in online learning. Facing those challenges, the teachers prepared the learning materials and online assessments long days before their teaching schedule. Sometimes, they also watched YouTube to find any tutorials of designing effective online assessments. 
Volume 7, Number 01, June 2021

"The teachers should prepare extra efforts or to prepare the materials, unusual materials and assessments. I try to prepare the materials, the assessments, long before the day I deliver the materials and assessments"

(Mawar)

Lastly, students' problems also contributed to the challenges of conducting online learning. Unconducive home situations and helping parents to work were the barriers for achieving the successful of online learning. Teachers told that some of their students were distracted by their unconducive home situations. Some noises might appear when students joined online learning. Even, sometimes the students' sister or brother activities intrude their focus. Meanwhile, one teacher who taught in a remote area reported that some of her students sent assignments lately because of helping their parents in the palm oil plantation full day. This happened because they lived in a remote area where the awareness of studying was very low. To face these challenges, the teachers gave their students extra time for submitting assignments as offering flexible teaching and assessments would be wise for coping unintended occasions in this pandemic time. This strategy was quite effective for tolerating the students with unconducive learning situations.

"When students are studying at home, their sisters or brothers may distract the students' focus or concentration"

\section{Discussion}

This study deals with the issue of online learning during the COVID-19 pandemic. Studies related to the online learning implementation have already been done by many researchers from various countries (e.g., Cai \& Wang, 2020; Xie \& Yang, 2020; Basilaia \& Kvavadze, 2020, Fitriani, Bandung, \& Kadri, 2020). The pandemic significantly affects the education system, in which the government shifts face-to-face learning into online learning. Online learning is considered to be the best solution for teaching and learning activities during this pandemic. However, this shifting provides a number of challenges, particularly for the teachers (Satar \& Akcan, 2018).

Correspondingly, this study revealed that teachers prepared learning materials and online assessments long days before their teaching schedule. This is supported by Nugroho and Mutiaraningrum (2020) and Nugroho, Ilmiani, and Rekha (2020) reporting that online learning consumes a lot of time to prepare the learning materials. Moreover, the unfamiliarity of using online learning platforms such as sending documents/files, creating tasks deadline, checking students' presence, submitting tasks, and archiving students' work becomes another great challenge for teachers in their online class (Sun et al., 2020). The teachers also reported that 
Renekso, Muslim, Lesagia, Teaching Online in Pandemic...

speaking was the most challenging skill to teach as many students were not confident to speak up in online speaking practices. Even, they were commonly quite passive in face-to-face classrooms. For some students, getting involved in online speaking practices are quite challenging since they might be worried if they will not understand or be understood. Likwise, getting flustered in using technology also contributes to the increase of online speaking anxiety (Jones, 2018). Additionally, several applications such as WhatsApp (Ahmed, 2019) and YouTube (Alwehaibi, 2015) can help the teachers to cope the technical problems and teachers' problems related to online learning. Although the teachers faced various challenges, the results showed that the EFL teachers have positive responses to online learning implementation during the pandemic.

In terms of learning materials, the Indonesian Ministry of Education and Culture provides materials for teachers and students during online learning through various platforms (Kemendikbud, 2020). EFL teachers believed that learning materials provided by trusted online learning platforms were reliable. However, some circumstances require teachers to evaluate and adapt the materials. Adapting materials is necessary to maximize the teaching materials' appropriateness in a context and adjust them based on the learning objectives (McDonough et al., 2015). Also, materials adaptation is focused in making the teaching more relevant and meaningful to the students. Thus, teachers should have the capability to evaluate and adapt the materials to make them more suitable for students.

In addition, the finding of the study also revealed that online learning provides an opportunity for teachers and students to upgrade their information technology (IT) skills. Online learning also supports the students to be more autonomous and adaptable. In the same way, Basilaia and Kvavadze (2020) revealed that online learning serves positive impact to education in terms of information technology adaptation. Essentially, the teachers get benefits from their experiences during online learning for post-pandemic time. Moreover, this study revealed that most of the teachers believed that online learning trained students to be more autonomous in finding materials through online resources. It is supported by Xie and Yang (2020), who claimed that online learning improves students' autonomous learning. Another research conducted by Cai and Wang (2020) showed that online learning can enhance students' autonomy by following several steps of online teaching methods based on protocolguided learning. 


\section{E. CONCLUSION}

Regarding to the findings and discussions, firstly this study reported that the majority of the EFL teacshers showed positive responses to the implementation of online learning during the pandemic. As the teachers had good access for online resources and experienced in managing online learning, they welcomed the changing of face-to-face classrooms to online learning. They believed that learning materials provided by trusted online learning platforms were reliable. However, materials adaptations were still to be done when necessary. In terms of teaching language skills, they argued that problem to teach online while reading and writing were less challenging. Moreover, they saw online learning as an opportunity for upgrading their information technology (IT) skills and literacy as well as for shaping students to be more resilient and adaptable. Last of all, they realized that online learning played an important role in bridging teachers, students and contents (learning materials).

Secondly, it was also confirmed by the EFL teachers that they faced some challenges during conducting online learning. The challenges were categorized into three namely technical problems, teachers' problems and students' problems. Allocating BOS (Bantuan Operasional Sekolah or School Operational Fund) for buying students internet quota, giving simpler tasks with low usage of internet data, recommending students to watch English learning programs at TVRI, asking some students to help others who did not have smartphones and using simpler application (WhatsApp) were done by the teachers to cope the technical problems. Then, preparing online learning materials and assessments long days before the schedule of teaching as well as watching YouTube tutorials for improving knowledge about online assessments were strategies to solve the teachers' problems. Meanwhile, the students' problems were handled by giving them extra time for finishing tasks.

The pedagogical implication of this study relates to the teacher readiness in embracing the future educational trends, transforming face-to-face classrooms to online learning. The pandemic indeed affected educational lives and forced us to employ online learning in order to maintain learning processes. Although conducting online learning in this pandemic time was not that easy, teachers might take value as they had opportunity to upgrade their IT skills and literacy. Some challenges appeared in online learning also trained them to be more experienced and adaptable. Most noteworthy, natural disasters, pandemic times and any difficult times will always motivate us to adopt highly innovation of information and communication technology (ICT) including online learning. Likewise, more teacher training for managing online learning should be provided by stakeholders including government, universities, and educational foundation/associations. Finally, further research focusing on 
Renekso, Muslim, Lesagia, Teaching Online in Pandemic...

English teachers' readiness for managing online learning in post pandemic era is highly recommended.

\section{REFERENCES}

Ahmed, S. (2019). Chat and Learn: Effectiveness of Using WhatsApp as a Pedagogical Tool to Enhance EFL Learners Reading and Writing Skills. International Journal of English Language and Literature Studies, https://doi.org/10.18488/journal.23.2019.82.61.68

Alwehaibi, H. O. (2015). The Impact of Using Youtube in EFL Classroom on Enhancing EFL Students' Content Learning. Journal of College Teaching \& Learning, 12, 121-126.

Anderson, T. (2008). The theory and practice of online learning. Athabasca University Press.

Basilaia, G., \& Kvavadze, D. (2020). Transition to online education in schools during a SARSCoV-2 coronavirus (COVID-19) pandemic in Georgia. Pedagogical Research, 5(4), 1-9.

Cai, R., \& Wang, Q. (2020). A six-step online teaching method based on protocol-guided learning during the COVID-19 epidemic: A case study of the first middle school teaching practice in Changyuan city, Henan province, China. Best Evidence in Chinese Education, 4(2), 529-534. https://doi.org/10.15354/bece.20.rp010

Carliner, S. (2004). An overview of online learning. Human Resource Development.

Code, J., Ralph, R., \& Forde, K. (2020). Pandemic designs for the future: perspectives of technology education teachers during COVID-19. Information and Learning Sciences, 121, 419-431. https://doi.org/10.1108/ILS-04-2020-0112

Creswell, J. W., \& Poth, C. N. (2018). Qualitative inquiry and research design: Choosing among five approaches. Sage publications.

Dabbagh, N., \& Kitsantas, A. (2012). Personal learning environments, social media, and selfregulated learning: A natural formula for connecting formal and informal learning. The Internet and Higher Education, 15(1), 3-8.

Dreamson, N. (2020). Online Design Education: Meta-Connective Pedagogy. International Journal of Art \& Design Education, 39(3), 483-497.

Fitriani, Y., Bandung, M., \& Kadri, M. K. (2020). Humanitatis Journal of Language and Literature Students ' Perspective of Online Learning o n Speaking Class During Covid19 Pandemic Humanitatis Journal of Language and Literature. Humanitatis Journal of Language and Literature, 7(1), 1-12.

Huang, R. H., Liu, D. J., Tlili, A., Yang, J. F., \& Wang, H. H. (2020). Handbook on facilitating flexible learning during educational disruption: The Chinese experience in maintaining undisrupted learning in COVID-19 Outbreak. Beijing: Smart Learning Institute of Beïing Normal University. 
Jones, C. (2018). An introduction to teaching speaking online - part 1. https://perma.cc/3P7UWT62

Kemdikbud. (2020). Cegah sebaran Covid-19 di satuan pendidikan, Kemdikbud gandeng swasta siapkan solusi belajar daring. https://perma.cc/KT9A-8N86

Knight, S. W. P. (2020). Establishing professional online communities for world language educators. Foreign Language Annals.

Lin, K.-M. (2011). e-Learning continuance intention: Moderating effects of user e-learning experience. Computers \& Education, 56(2), 515-526.

Mahmood, S. (2020). Instructional strategies for online teaching in COVID-19 pandemic. Human Behavior and Emerging Technologies, 1-5. https://doi.org/10.1002/hbe2.218

McDonough, J., Shaw, C., \& Masuhara, H. (2015). Materials and Methods in ELT (Third Edit). Wiley-Blackwell.

Miles, M. B., \& Huberman, A. M. (1994). Qualitative data analysis: An expanded sourcebook. sage.

Miles, M. B., Huberman, A. M., \& Saldana, J. (2014). Qualitative data analysis: A methods sourcebook (3rd ed.). SAGE Publications.

Moorhouse, B. L. (2020). Adaptations to a face-to-face initial teacher education course 'forced'online due to the COVID-19 pandemic. Journal of Education for Teaching, 1-3.

Nugroho, A., Ilmiani, D., \& Rekha, A. (2020). EFL Teachers' Challenges and Insights of Online Teaching amidst Global Pandemic. METATHESIS: JOURNAL OF ENGLISH LANGUAGE LITERATURE AND TEACHING, 4(3), 277-291. https://doi.org/10.31002/metathesis.v4i3.3195

Nugroho, A., \& Mutiaraningrum, I. (2020). EFL teachers' beliefs and practices about digital learning of English. EduLite: Journal of English Education, Literature and Culture, 5(2), 304. https://doi.org/10.30659/e.5.2.304-321

Owusu-Fordjour, C., Koomson, C. K., \& Hanson, D. (2020). The impact of Covid-19 on learning-the perspective of the Ghanaian student. European Journal of Education Studies.

Satar, H. M., \& Akcan, S. (2018). Pre-service EFL teachers' online participation, interaction, and social presence. Language Learning and Technology, 22(1), 157-184.

Selwyn, N. (2012). Making sense of young people, education and digital technology: The role of sociological theory. Oxford Review of Education, 38(1), 81-96.

Singh, V., \& Thurman, A. (2019). How many ways can we define online learning? A systematic literature review of definitions of online learning (1988-2018). American Journal of Distance Education, 33(4), 289-306.

Stodel, E. J., Thompson, T. L., \& MacDonald, C. J. (2006). Learners' perspectives on what is missing from online learning: Interpretations through the community of inquiry 
Renekso, Muslim, Lesagia, Teaching Online in Pandemic...

framework. The International Review of Research in Open and Distributed Learning, 7(3).

Sun, X., Zou, J., Li, L., \& Luo, M. (2020). A blockchain-based online language learning system. Telecommunication Systems. https://doi.org/10.1007/s11235-020-00699-1

Vlachopoulos, D. (2020). COVID-19: Threat or Opportunity for Online Education? Higher Learning Research Communications, 10(1). https://doi.org/DOI:10.18870/hlrc.v10i1.1179

World Health Organization. (2020). Key messages and actions for COVID-19 prevention and control in schools. https://perma.cc/S9L8-U3UL

Xie, Z., \& Yang, J. (2020). Autonomous learning of elementary students at home during the COVID-19 Epidemic: A case study of the Second Elementary School in Daxie, Ningbo, Zhejiang province, China. Best Evidence in Chinese Education, 4(2), 535-541. https://doi.org/10.15354/bece.20.rp009

Yin, R. K. (2016). Qualitative research from start to finish (2nd ed.). Guilford publications.

Zia, A. (2020). Exploring factors influencing online classes due to social distancing in COVID-19 pandemic: a business students perspective. The International Journal of Information and Learning Technology, 37(4), 197-211. https://doi.org/10.1108/IJILT-052020-0089 